\title{
Seismic performance of four-storey masonry infilled reinforced concrete frame building
}

\author{
Isyana Ratna Hapsari ${ }^{1, *}$, Senot Sangadji ${ }^{2}$, and Stefanus Adi Kristiawan ${ }^{2}$ \\ ${ }^{1}$ Master Program, Civil Engineering Department, Faculty of Engineering, Universitas Sebelas Maret, \\ Surakarta, Indonesia \\ 2 SMARTQuake and SMARTCrete Research Group, Civil Engineering Department, Faculty of \\ Engineering, Universitas Sebelas Maret, Surakarta, Indonesia
}

\begin{abstract}
Masonry infilled reinforced concrete frames are a structural system commonly used for low-to-mid-rise buildings. Generally, this type of structure is modelled as an open frame neglecting the strength and stiffness contribution of the masonry infilled panel. In order to describe realistic behaviour under lateral loading, this paper evaluates the seismic performance of the building by modelling the contribution of masonry as a compression strut acting diagonally in the panel. The non-linear static procedure is employed by subjecting the building to pushover loads. The performance of the building is then analysed based on the obtained capacity curve. Seismic performance is assessed in terms of building fragility which is the conditional probability of exceeding certain damage state for a given ground shaking intensity. Fragility functions eventually are expressed as series of log-normal curves of both the open and masonry infilled reinforced concrete frame. Based on this study, the infilled frame can resist a maximum load of $20.3 \times 10^{3} \mathrm{kN}$, while the open frame is only able to withstand a maximum load of $15.2 \times 10^{3} \mathrm{kN}$. From the fragility curve, it can be concluded that the probability of the infilled frame to reach a certain damage state is lower than that of the open frame.
\end{abstract}

\section{Introduction}

A masonry infilled wall is regarded as a non-structural component that only gives a gravitational load effect to the structure. Hence, the masonry infilled frame building is generally modelled as an open frame structure omitting the strength and stiffness contribution of the infilled wall. In reality, the infilled wall consists of bricks and mortar components which, as a composite material, provides certain strength and stiffness to the structural frame. The magnitude of the strength and stiffness of the built masonry are diverse and they are greatly influenced by the quality of the materials and workmanship [1]. Based on the previous research, it is shown that the probability of collapse of the masonry infilled structure is smaller compared to the open frame model [2]. The finding highlights the important contribution of masonry infilled to the behaviour of the structural frame.

\footnotetext{
${ }^{*}$ Corresponding author: isyana rh@student.uns.ac.id
} 
Indonesia is a country with numerous incidences of earthquakes at a variety of intensities. The incidences can bring catastrophic consequences to the people and properties. For this reason, a reliable seismic performance of building has to be endorsed to guarantee the damage induced by the seismic load is within an acceptable limit. This can be achieved by a realistic analysis of structure and an appropriate quantification of damage state limit when the building is subjected to various seismic intensities. In this regard, this study employs a macro model of masonry infilled wall in the form of an equivalent diagonal compression strut $[3,4]$ to take into account its contribution to the seismic performance of the building.

In addition to the material and structural modelling, the accuracy of building seismic performance also depends on the correct approach in determining the criteria for damage on which the seismic performance is evaluated. For the current study, seismic performance is assessed on the basis of the fragility curve. The fragility curve provides complete information on the probabilities of various levels of building damage due to various seismic intensities $[5,6]$. The limit of damage states adopted in this study refers to the criteria set by HAZUSMH MR5 [7], ATC 40 [8] and Silva et al [9]. Based on the above approaches, the improved seismic performance associated with the masonry infilled wall contribution is then quantified by comparing the performance of four-storey masonry infilled reinforced concrete frame structure with that of the open frame structure.

\section{Modelling of the building}

\subsection{Open frame structure}

Figure 1 (left) gives a visual information of the layout of the open frame building investigated in this study. The building is a four-storey structure and used for residential purpose. The building can be classified to be the Mid-Rise Irregular building group. The irregularity is due to the variation of material qualities, variation of beam/column sizes and an unequal plate placement of each floor. Table 1 provides information about the element classes, dimension and their property (concrete compressive strength).
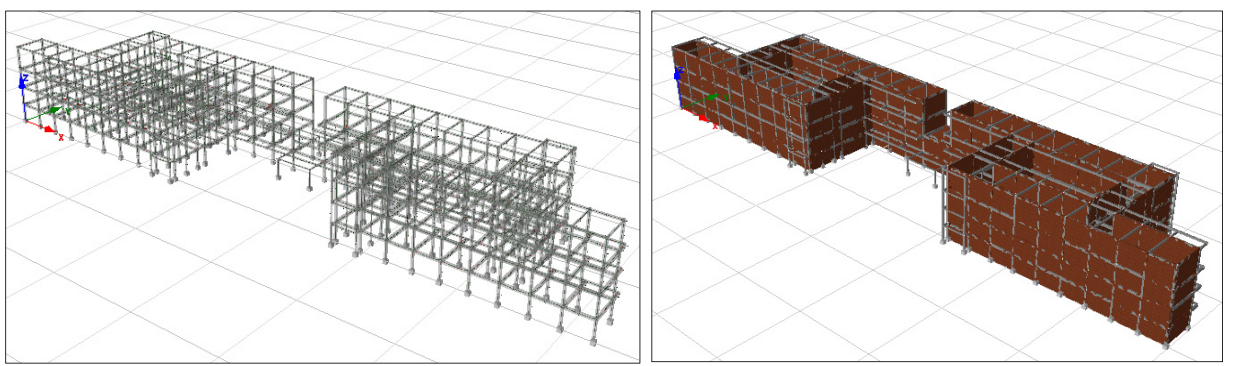

Fig. 1. 3D Lay Out Structure Open Frame (left) - Infilled Frame (right).

For the open frame structure, the infilled wall is considered only to cause a gravitational load to the beam below it. This load is calculated in units of ton $/ \mathrm{m} '$. The beam also supports either floor or roof plate. The floor or rooftop load is calculated using tributary area method. Both infilled wall and floor/rooftop loads are distributed evenly to the beam below them.

In this study, the Mander et al. [10] model of non-linear with constant confinement is used to model the concrete. Meanwhile, the Menegotto-Pinto [11] model with Filippou hardening isotropic rule [12] is chosen for modelling the reinforcing steel. 
Table 1. Element classes and dimension.

\begin{tabular}{|c|c|c|c|c|c|}
\hline Element Classes & $\begin{array}{c}\text { Beam size } \\
\left(\mathbf{m m}^{2}\right)\end{array}$ & $\begin{array}{c}\text { Concrete } \\
\text { compressive } \\
\text { strength of } \\
\text { beam (MPa) }\end{array}$ & $\begin{array}{l}\text { Column } \\
\text { size } \\
\left(\mathbf{m m}^{2}\right)\end{array}$ & $\begin{array}{c}\text { Concrete } \\
\text { compressive } \\
\text { strength of } \\
\text { column } \\
(\mathrm{MPa}) \\
\end{array}$ & $\begin{array}{c}\text { Slab } \\
\text { thickness } \\
(\mathrm{mm})\end{array}$ \\
\hline \multicolumn{6}{|l|}{ a. $1,2,3$ FLOOR } \\
\hline 1. $\quad$ Primary type 1 & $300 \times 400$ & 28 & $300 \times 400$ & 30 & 140 \\
\hline 2. $\quad$ Primary type 2 & $300 \times 500$ & 28 & & & \\
\hline 3. $\quad$ Primary type 3 & $300 \times 300$ & 25 & & & \\
\hline 4. $\quad$ Primary type 4 & $300 \times 600$ & 24 & & & \\
\hline 5. $\quad$ Primary type 5 & $250 \times 400$ & 28 & & & \\
\hline 6. $\quad$ Secondary type 1 & $200 \times 300$ & 26 & $150 \times 150$ & 30 & \\
\hline 7. Secondary type 2 & $300 \times 400$ & 24 & $150 \times 300$ & & \\
\hline 8. $\quad$ Secondary type 3 & $150 \times 300$ & 26 & & & \\
\hline 9. $\quad$ Secondary type 4 & $150 \times 250$ & 28 & & & \\
\hline $\begin{array}{ll}10 . & \text { Secondary type } 5 \\
\text { (only 1st floor) }\end{array}$ & $150 \times 200$ & 30 & & & \\
\hline \multicolumn{6}{|l|}{ b. ROOF } \\
\hline 11. Primary type 1 & $200 \times 300$ & 26 & $300 \times 400$ & 30 & 120 \\
\hline 12. Primary type 2 & $300 \times 400$ & 28 & & & \\
\hline 13. Secondary type 1 & $200 \times 300$ & 26 & $150 \times 150$ & 30 & \\
\hline 14. Secondary type 2 & $150 \times 250$ & 28 & $150 \times 300$ & & \\
\hline 15. Secondary type 3 & $150 \times 300$ & 26 & & & \\
\hline
\end{tabular}

\subsection{Masonry infilled frame structure}

It is expected that the infilled wall contributes to the strength and stiffness of the frame structure. A macro modelling of masonry infilled as an equivalent diagonal compression strut is adopted in this study [3,4]. A single strut modelling (see Figure 2) is used to represent masonry behavior. Despite the simplicity of its mathematical formulas, this model can still provide an adequate estimation of the infilled frame stiffness value against lateral load [13]. Table 2 indicates parameters associated with the masonry properties for the structural modelling. A typical value of Indonesian masonry compressive strength of $0.919 \mathrm{MPa}$ as given in [14] is used for the current study.

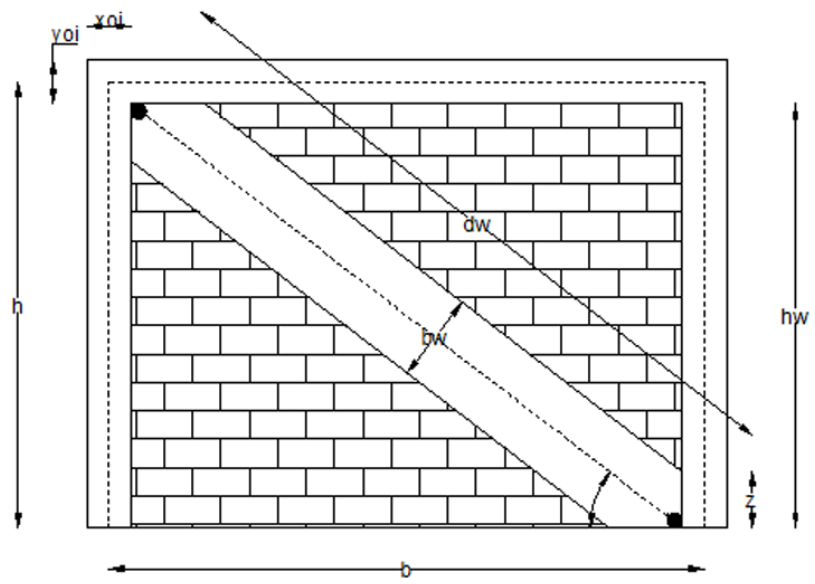

Fig. 2. Macro modelling of masonry infilled. 
Table 2. Infilled parameters, equations and references.

\begin{tabular}{|c|c|c|c|c|}
\hline Infilled Panel Model Parameters & Unit & $\begin{array}{c}\text { Used } \\
\text { Value } \\
\end{array}$ & Equation & Ref \\
\hline \multicolumn{5}{|l|}{ 1.Mechanical Properties } \\
\hline a. Elastic Young's Modulus, $E_{m}$ & $\mathrm{MPa}$ & varies & $E_{m}=f m \theta / \varepsilon_{m}$ & \\
\hline $\begin{array}{l}\text { b. Mean diagonal compressive } \\
\text { strength, } f m \theta\end{array}$ & $\mathrm{MPa}$ & varies & $f m \theta=f_{1 .} \sin ^{2} \theta$ & [3] \\
\hline c. Tensile Strength, $f t$ & $\mathrm{MPa}$ & 0 & & {$[15]$} \\
\hline d. Bond shear strength, $\tau_{0}$ & $\mathrm{MPa}$ & 0.3 & & {$[15]$} \\
\hline e. Coefficient of friction, $\mu$ & & 0.62 & & {$[16]$} \\
\hline f. Maximum shear stress, $\tau_{\max }$ & $\mathrm{MPa}$ & 1 & & {$[15]$} \\
\hline g. Strain at max stress, $\left(\varepsilon_{m}\right)$ & $\mathrm{MPa}$ & 0.0012 & & {$[15]$} \\
\hline h. Ultimate strain, $\left(\varepsilon_{u}\right)$ & $\mathrm{MPa}$ & 0.024 & $\mathcal{E}_{u}=20 . \varepsilon_{m}$ & [15] \\
\hline i. Closing strain, $\left(\varepsilon_{c l}\right)$ & $\mathrm{MPa}$ & 0.003 & & {$[15]$} \\
\hline j. Specific Weight, $W$ & $\mathrm{~N} / \mathrm{mm}^{3}$ & $\begin{array}{l}1.7 \mathrm{E}- \\
005\end{array}$ & & \\
\hline \multicolumn{5}{|l|}{ 2.Empirical Properties } \\
\hline $\begin{array}{l}\text { a. Starting Unloading Stiffness Factor, } \\
\left(\gamma_{u n}\right)\end{array}$ & & 1.7 & & {$[15]$} \\
\hline b. Strain Reloading Factor, $\left(\alpha_{r e}\right)$ & & 0.2 & & {$[15]$} \\
\hline c. Strain Inflection Factor, $\left(\alpha_{r h}\right)$ & & 0.7 & & {$[15]$} \\
\hline $\begin{array}{l}\text { d. Complete Unloading Strain Factor, } \\
\left(\beta_{a}\right)\end{array}$ & & 2 & & {$[15]$} \\
\hline e. Stress Inflection Factor, $\left(\beta_{c h}\right)$ & & 0.9 & & {$[15]$} \\
\hline f. Zero Stress Stiffness Factor, $\left(\gamma_{p l u}\right)$ & & 1 & & {$[15]$} \\
\hline g. Reloading Stiffness Factor, $\left(\gamma_{p l r}\right)$ & & 1.1 & & {$[15]$} \\
\hline $\begin{array}{l}\text { h. Plastic Unloading Stiffness Factor, } \\
e_{x 1}\end{array}$ & & 3 & & {$[15]$} \\
\hline i. Repeated Cycle Strain Factor, $e_{x 2}$ & & 1 & & [15] \\
\hline j. Reduction Shear Factor, $\left(\alpha_{s}\right)$ & MPa & 1.43 & & [3] \\
\hline k. Out-of-plane Failure Drift & $\%$ & 1 & & [17] \\
\hline $\begin{array}{l}\text { 1. Proportion of stiffness assigned to } \\
\text { shear, } \gamma_{s}\end{array}$ & $\%$ & 70 & & [15] \\
\hline \multicolumn{5}{|l|}{ 3.Geometrical Properties } \\
\hline a. Panel Thickness, $t_{w}$ & $\mathrm{~mm}$ & 150 & & \\
\hline b. Dimensionless relative stiffness, $\lambda_{h}$ & & & $\lambda_{h}=h^{4} \sqrt{\frac{E_{m} t_{w} \sin (2 \theta)}{4 E_{c} I_{c} h_{w}}}$ & [3] \\
\hline c. Width of strut, $b_{w l}$ & $\mathrm{~mm}$ & varies & $b_{w}=0.175(\lambda . h)^{-0.4} d_{w}$ & $\begin{array}{l}{[18,} \\
19]\end{array}$ \\
\hline d. Strut Area $1, A m_{1}$ & $\mathrm{~mm}^{2}$ & varies & $A m_{l}=b w_{l} . t_{i n f}$ & \\
\hline e. Strut Area $2, A m_{2}$ & $\%$ & 70 & $A m_{2}=b w_{\text {cracked }} / b w_{\text {uncracked }}(7)$ & [3] \\
\hline f. Strut Area Reduction Strain, $\left(\varepsilon_{l}\right)$ & & 0.0006 & & [20] \\
\hline g. Residual Strut Area Strain, $\left(\varepsilon_{2}\right)$ & & 0.001 & & [20] \\
\hline h. Equivalent Contact Length, $h_{z}$ & $\mathrm{~mm}$ & 0 & Diagonal Single strut & \\
\hline i. Horizontal Offsets, $x_{o i}$ & $\%$ & varies & $x o i=\frac{0.5 \text { column width }}{\text { width of infill panel }}$ & {$[15]$} \\
\hline j. Vertical Offsets, $y_{o i}$ & $\%$ & varies & $y o i=\frac{0.5 \text { beam depth }}{\text { height of infill panel }}$ & {$[15]$} \\
\hline
\end{tabular}




\section{Seismic performance analysis}

\subsection{Structural analysis}

The structural response of both the open frame and the masonry infilled frame structure are evaluated by performing a non-linear static pushover analysis first. The analysis is carried out using a finite element software (Seismostruct) [21]. The main output of this analysis is a capacity curve.

\subsection{Developing fragility curve}

\subsubsection{Converting the capacity curve into a spectrum capacity curve}

The first step in the development of a fragility curve is by converting the capacity curve obtained from the non-linear pushover analysis to a spectrum capacity curve. The formulae used to convert the capacity curve (base shear-displacement) into spectral capacity (spectral acceleration versus spectral displacement) based on ATC-40 [8] are as follows:

$$
\begin{gathered}
S a=\frac{V / W}{\alpha l} \\
S d=\frac{\Delta \text { roof }}{\text { PF1 } \text { Øroofl }}
\end{gathered}
$$

and $P F 1$ can be calculated as follows [7]:

$$
\begin{gathered}
P F 1=\left[\frac{\sum_{i=1}^{N}(w i . \varnothing i 1) / g}{\sum_{i=1}^{N}\left(w i . \varnothing i 1^{2}\right) / g}\right] \\
\alpha 1=\frac{\left[\sum_{i=1}^{N}(w i . \varnothing i 1) / g\right]^{2}}{\left[\sum_{i=1}^{N}(w i) / g\right]\left[\sum_{i=1}^{N}\left(w i . \varnothing i 1^{2}\right) / g\right]}
\end{gathered}
$$

The notations of $S a, S d, P F 1, \alpha 1, \varnothing i 1, V, W, \Delta r o o f$, and $(w i) / g$ refer to spectral acceleration, spectral displacement, modal participation of $1^{\text {st }}$ mode, modal mass coefficient of $1^{\text {st }}$ mode, $1^{\text {st }}$ amplitude pushover for level $i$, base shear, weight of structure, roof displacement, and mass on level $i$, respectively.

\subsubsection{Determining the damage states}

There are several ways to determine the damage states of the structure. They may be calculated on the basis of the inter-story drift ratio, the maximum base shear capacity, the yield displacement $\left(d_{y}\right)$ and ultimate displacement $\left(d_{u}\right)$, the material strain level, etc. [7-9,22]. This study determines the damage states of the structure using the inter-story drift ratio criteria as set in the HAZUS-MH MR5 [7] and ATC 40 [8]. In addition, criteria of damage states based on the maximum base shear capacity as suggested by Silva et al [9] are also adopted. 
The HAZUS-MH MR5 method classifies the damage states into four categories i.e. Slight, Moderate, Extensive and Complete. Table 3 shows the inter-story drift ratio criterion on which the respective structural damage state is defined.

Table 3. The HAZUS-MH MR5 inter-story drift ratio of structural damage states.

\begin{tabular}{|c|c|c|c|c|}
\hline \multirow[t]{2}{*}{ Model Building Type } & \multicolumn{4}{|c|}{ Structural Damage States } \\
\hline & Slight & Moderate & Extensive & Complete \\
\hline \multicolumn{5}{|c|}{ Low-Rise Buildings - High - Code Design Level } \\
\hline $\mathrm{W} 1, \mathrm{~W} 2$ & 0.004 & 0.012 & 0.040 & 0.100 \\
\hline S1 & 0.006 & 0.012 & 0.030 & 0.080 \\
\hline $\mathrm{C} 1, \mathrm{~S} 2$ & 0.005 & 0.010 & 0.030 & 0.080 \\
\hline $\mathrm{C} 2$ & 0.004 & 0.010 & 0.030 & 0.080 \\
\hline S3, S4, PC1, PC2, RM1, RM2 & 0.004 & 0.008 & 0.024 & 0.070 \\
\hline \multicolumn{5}{|c|}{ Low-Rise Buildings - Moderate - Code Design Level } \\
\hline W1, W2 & 0.004 & 0.010 & 0.031 & 0.075 \\
\hline S1 & 0.006 & 0.010 & 0.024 & 0.060 \\
\hline $\mathrm{C} 1, \mathrm{~S} 2$ & 0.005 & 0.009 & 0.023 & 0.060 \\
\hline $\mathrm{C} 2$ & 0.004 & 0.008 & 0.023 & 0.060 \\
\hline S3, S4, PC1, PC2, RM1, RM2 & 0.004 & 0.007 & 0.019 & 0.053 \\
\hline \multicolumn{5}{|c|}{ Low-Rise (LR) Buildings - Low - Code Design Level } \\
\hline W1, W2 & 0.004 & 0.010 & 0.031 & 0.075 \\
\hline S1 & 0.006 & 0.010 & 0.020 & 0.050 \\
\hline $\mathrm{C} 1, \mathrm{~S} 2$ & 0.005 & 0.008 & 0.020 & 0.050 \\
\hline $\mathrm{C} 2$ & 0.004 & 0.008 & 0.020 & 0.050 \\
\hline S3, S4, PC1, PC2, RM1, RM2 & 0.004 & 0.006 & 0.016 & 0.044 \\
\hline S5, C3, URM & 0.003 & 0.006 & 0.015 & 0.035 \\
\hline \multicolumn{5}{|c|}{ Low-Rise (LR) Buildings - Pre - Code Design Level } \\
\hline W1, W2 & 0.003 & 0.008 & 0.025 & 0.060 \\
\hline S1 & 0.005 & 0.008 & 0.016 & 0.040 \\
\hline $\mathrm{C} 1, \mathrm{~S} 2$ & 0.004 & 0.006 & 0.016 & 0.040 \\
\hline $\mathrm{C} 2$ & 0.003 & 0.006 & 0.016 & 0.040 \\
\hline S3, S4, PC1, PC2, RM1, RM2 & 0.003 & 0.005 & 0.013 & 0.035 \\
\hline S5, C3, URM & 0.002 & 0.005 & 0.012 & 0.028 \\
\hline \multicolumn{5}{|c|}{ Mid - Rise Buildings } \\
\hline $\begin{array}{l}\text { Mid-Rise Building } \\
\text { Types }\end{array}$ & $2 / 3 * \mathrm{LR}$ & $2 / 3 * \mathrm{LR}$ & $2 / 3 * \mathrm{LR}$ & $2 / 3 * \mathrm{LR}$ \\
\hline \multicolumn{5}{|c|}{ High - Rise Buildings } \\
\hline $\begin{array}{l}\text { Mid-Rise Building } \\
\text { Types }\end{array}$ & $1 / 2 * \mathrm{LR}$ & $1 / 2 * \mathrm{LR}$ & $1 / 2 * \mathrm{LR}$ & $1 / 2 * \mathrm{LR}$ \\
\hline
\end{tabular}

The ATC-40 method defines the seismic performance into four levels i.e. Immediate Occupancy (OI), Damage Control (DC), Life Safety (LS), and Structural Stability (SS). The performance level is determined on the basis of the maximum total drift. The maximum total drift is defined as the inter-story drift at the performance point displacement. Table 4 shows the criterion of the maximum total drift for each performance level. These performance levels are adopted in this study to represent the damage states. Furthermore, since the criterion of DC is given as a range of value between IO and LS, this criterion of damage state is omitted in this current study. 
Table 4. Deformation limits.

\begin{tabular}{|c|c|c|c|c|}
\hline \multirow{2}{*}{$\begin{array}{c}\text { Interstory Drift } \\
\text { Limit }\end{array}$} & \multicolumn{4}{|c|}{ Performance Level (Damage States) } \\
\cline { 2 - 5 } & IO & DC & LS & SS $^{*}$ \\
\hline Maximum total drift & 0.01 & $0.01-0.02$ & 0.02 & $0.33 \frac{V_{I}}{P_{I}}$ \\
\hline
\end{tabular}

* $V_{i}$ and $P_{i}$ are respectively total lateral shear force and total gravity load at story $i$;

Another criterion of damage state used in this study is that suggested by Silva et al [9]. They determined three levels of structural damage as follows:

- Limit state 1 (LS1): top displacement at $75 \%$ of the maximum base shear capacity is achieved

- Limit state 2 (LS2): top displacement at the maximum base shear capacity is achieved

- Limit state 3(collapse)-(LS3): top displacement when the base shear capacity decreases $20 \%$

\subsubsection{Establishing the fragility curve}

The probability of the structure to reach a damage state limit for a given seismic intensity is affected by uncertainties with respect to the structural capacity, the seismic intensity (spectrum demand) and the assigned value of damage state limit. The uncertainties are quantified in term of the standard deviation of irregularities $(\beta)$. The standard deviation of the total uncertainty $\left(\beta_{\mathrm{ds}}\right)$ is composed of three standard deviations: the standard deviation representing, respectively, the uncertainty of structural capacity $\left(\beta_{\mathrm{C}}\right)$ [23], spectrum demand $\left(\beta_{\mathrm{d}}\right)$, and damage limit value of the structure $\left(\beta_{\mathrm{M}(\mathrm{ds})}\right)$. The following equations govern the relationship between the three standard deviations to compose the standard deviation of the total uncertainty $\left(\beta_{\mathrm{ds}}\right)[7]$ :

$$
\begin{gathered}
\beta_{c}=\sqrt{\ln \left(\frac{s^{2}}{m^{2}}+1\right)} \\
\left(\beta_{d s}\right)=\sqrt{\left[\left(\operatorname{CONV}\left[\beta_{c}, \beta_{d}\right]\right)\right]^{2}+\left[\beta_{M(d s)}\right]^{2}}
\end{gathered}
$$

where:

$\mathrm{m}=$ the mean of non-logarithmized variables

$\mathrm{s}=$ the standard deviation of the non-logarithmized

$\beta d=0.45$ (for short period) and $\beta \mathrm{d}=0.5$ (for long period)

The fragility curve can be derived from the fragility function with an assumption that the distribution of seismic damage is presented as a cumulative standard lognormal distribution function. The probabilities of various states of structural damage are determined by the following formula [23]:

$$
\mathrm{P}\left(\mathrm{ds} \mid S_{a} \text { or } S d\right)=\Phi\left(\frac{1}{\beta_{d s}}\right) \ln \left(\frac{S a \text { or } S d}{S a \cdot d s \text { or } S d \cdot d \mathrm{~s}}\right)
$$

where $\Phi$ is the standard normal cumulative distribution function; Sa.ds or $S d . d s$ are the spectral acceleration or spectral displacement necessary to cause a specified damage state. 


\section{Results and discussion}

\subsection{Comparison of capacity curve}

The capacity curve is a curve describing the relationship between the base shear versus the displacement when the structure is subjected to pushover load. For the building under study, the curve is formed by first setting the target displacement of $0.294 \mathrm{~m}(2 \%$ of the height $)$ and the iteration is carried out as much as 98 steps. The performance limit criteria of the structure i.e. frame element chord rotation capacity and shear capacity refer to EUROCODE 8 [24]. The comparison between the capacity curves resulted from the analysis of the open frame structure versus the infilled frame can be seen in Figure 3. These curves are obtained when the lateral load is performed on the weakest axis of the structure (y-axis).

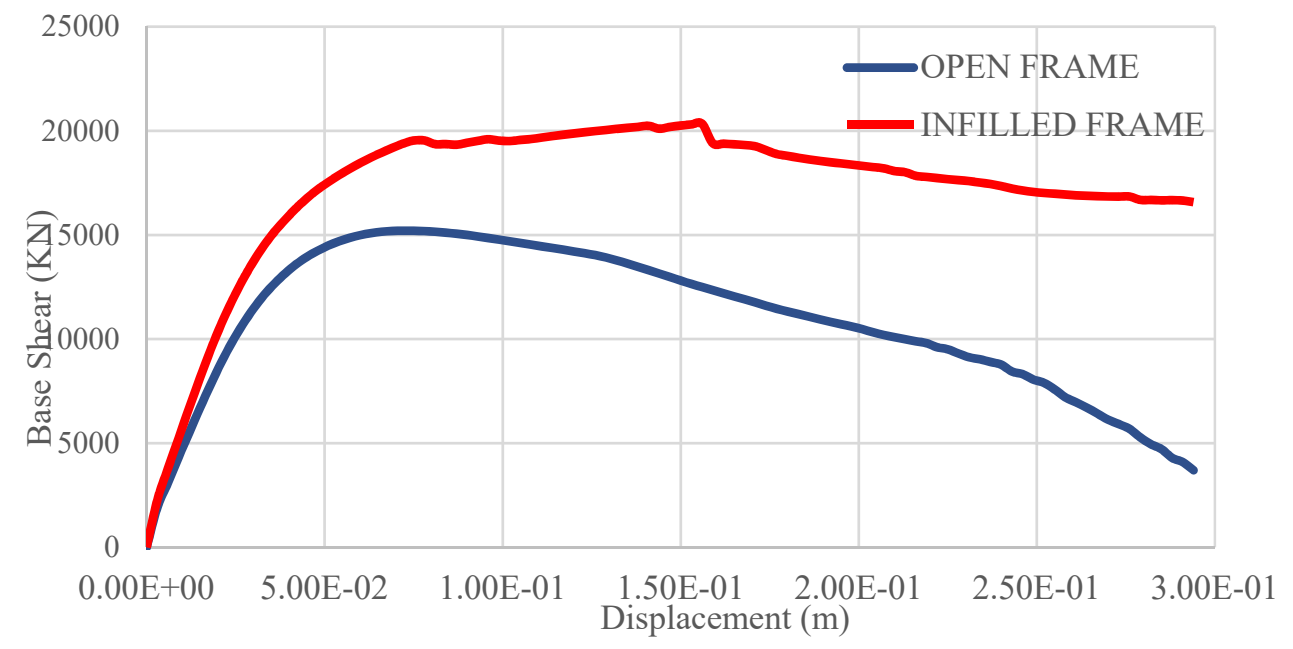

Fig. 3. Capacity curve of the open frame and infilled frame.

It can be seen from Figure 3 that the infilled frame structure is capable of receiving a maximum lateral load of $20.3 \times 10^{3} \mathrm{kN}$ while the corresponding load for the open frame is only $15.2 \times 10^{3} \mathrm{kN}$. The result confirms that the infilled frame has a better resistance against lateral load than the open frame (an increase of 33\%). This is related to the influence of the strength and the stiffness of masonry modelled in the infilled frame.

\subsection{Fragility analysis}

\subsubsection{Converting the capacity curve into a spectrum capacity curve}

Table 5. Pushover Mode Factor for Open Frame (top) - Infilled Frame (bottom).

\begin{tabular}{|l|c|c|c|c|c|c|}
\hline $\begin{array}{c}\text { OPEN } \\
\text { FRAME }\end{array}$ & $\mathbf{W}(\mathbf{k N )}$ & $\mathbf{m}$ & $\boldsymbol{\phi}(\mathbf{m})$ & $\mathbf{\Phi 2}$ & $\mathbf{m} \mathbf{x} \boldsymbol{\phi}$ & $\mathbf{m} \mathbf{x} \boldsymbol{\phi 2}$ \\
\hline roof & 8523.24 & 868.83 & $3.00 \mathrm{E}-03$ & $9.00 \mathrm{E}-06$ & $2.61 \mathrm{E}+00$ & $7.82 \mathrm{E}-03$ \\
\hline 3rd floor & 9896.33 & 1008.80 & $2.18 \mathrm{E}-03$ & $4.74 \mathrm{E}-06$ & $2.20 \mathrm{E}+00$ & $4.78 \mathrm{E}-03$ \\
\hline 2nd floor & 10030.27 & 1022.45 & $1.51 \mathrm{E}-03$ & $2.28 \mathrm{E}-06$ & $1.54 \mathrm{E}+00$ & $2.33 \mathrm{E}-03$ \\
\hline 1st floor & 10614.01 & 1081.96 & $6.01 \mathrm{E}-04$ & $3.61 \mathrm{E}-07$ & $6.50 \mathrm{E}-01$ & $3.91 \mathrm{E}-04$ \\
\hline$\sum$ & 39063.85 & 3982.04 & $7.29 \mathrm{E}-03$ & $1.64 \mathrm{E}-05$ & $7.00 \mathrm{E}+00$ & $1.53 \mathrm{E}-02$ \\
\hline
\end{tabular}




\begin{tabular}{|l|c|c|c|c|c|c|}
\hline $\begin{array}{c}\text { INFILLED } \\
\text { FRAME }\end{array}$ & $\mathbf{W}(\mathbf{k N )}$ & $\mathbf{m}$ & $\boldsymbol{\Phi}(\mathbf{m})$ & $\boldsymbol{\Phi}^{\mathbf{2}}$ & $\mathbf{m} \mathbf{x} \boldsymbol{\phi}$ & $\mathbf{m} \mathbf{x} \boldsymbol{\phi}^{\mathbf{2}}$ \\
\hline roof & 8523.24 & 868.83 & $3.00 \mathrm{E}-03$ & $9.00 \mathrm{E}-06$ & $2.61 \mathrm{E}+00$ & $7.82 \mathrm{E}-03$ \\
\hline 3rd floor & 9896.33 & 1008.80 & $2.28 \mathrm{E}-03$ & $5.19 \mathrm{E}-06$ & $2.30 \mathrm{E}+00$ & $5.24 \mathrm{E}-03$ \\
\hline 2nd floor & 10030.27 & 1022.45 & $1.61 \mathrm{E}-03$ & $2.58 \mathrm{E}-06$ & $1.64 \mathrm{E}+00$ & $2.64 \mathrm{E}-03$ \\
\hline 1st floor & 10614.01 & 1081.96 & $6.54 \mathrm{E}-04$ & $4.28 \mathrm{E}-07$ & $7.08 \mathrm{E}-01$ & $4.63 \mathrm{E}-04$ \\
\hline$\sum$ & 39063.85 & 3982.04 & $7.54 \mathrm{E}-03$ & $1.72 \mathrm{E}-05$ & $7.26 \mathrm{E}+00$ & $1.62 \mathrm{E}-02$ \\
\hline
\end{tabular}

Table 5 gives the pushover mode factor for both the open frame and the infilled frame structure. The parameters of the pushover mode factor are obtained from the eigenvalue and $\log$ report of the pushover analysis. These parameters (node masses $=\mathrm{m}, \emptyset \mathrm{il}=$ amplitude of pushover mode at $\mathrm{i}^{\text {th }}$ ) are then used as inputs to calculate $\alpha 1$ and $P F 1$ using Equation 12 and 13. The value of $\alpha 1$ and $P F 1$ for the open frame structure is 0.80 and 1.37, respectively. The corresponding value for the infilled frame is 0.82 and 1.35, respectively. Based on the obtained values of $\alpha 1$ and $P F 1$ as given above, the capacity curve can be presented into Acceleration Displacement Response Spectrum (ADRS) format using Equations 10 and 11. The obtained spectrum capacity curve is presented in Figure 4.

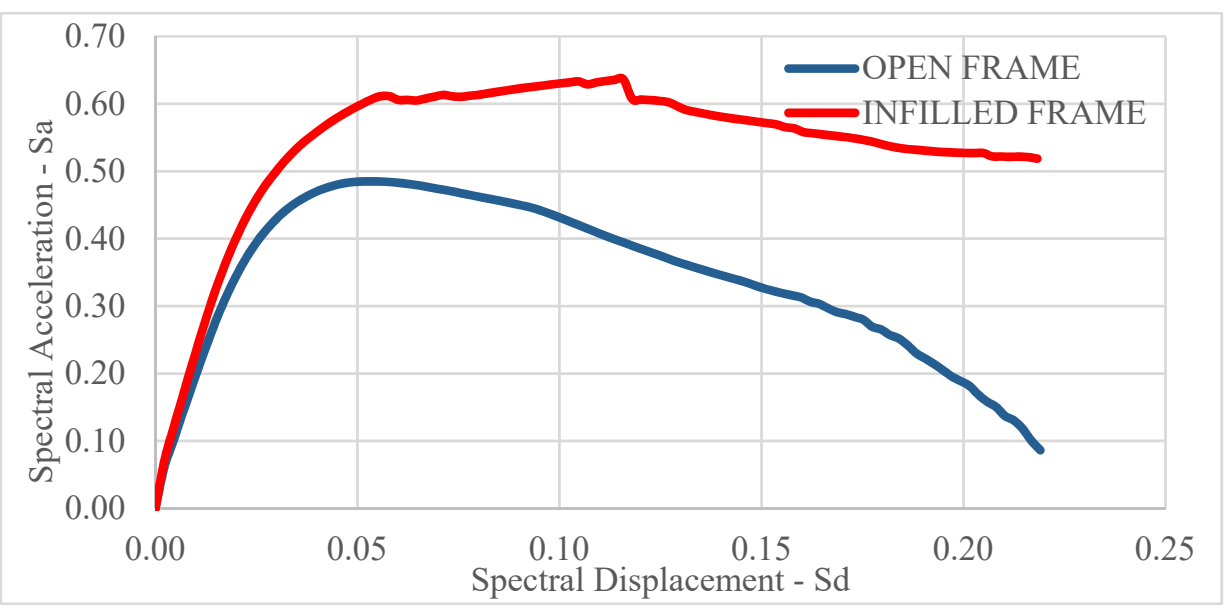

Fig. 4. Spectrum capacity of the open frame and infilled frame.

\subsubsection{Determining the damage states}

The damage states (see sub-section 3.2.2) as defined by the HAZUS-MH MR5 [7], ATC 40 [8] and Silva et al [9] are calculated and then used to identify the spectral displacement of Figure 4 at which the respective damage state occurs. Recapitulation of spectral displacements $(\mathrm{Sd})$ representing various damage states can be seen in Table 6 and 7 .

\subsubsection{Establishing the fragility curve}

The first step in forming the fragility curve is to calculate the standard deviation $(\beta)$ representing various uncertainties. Based on the eigen analysis, the structures have a period of 0.36 seconds (open frame) and 0.31 seconds (infilled frame) for the first mode. Hence, both structures belong to the short period structure (i.e a period of less than 3.5 seconds). For this type of structure, the dispersion demand $\left(\beta_{\mathrm{d}}\right)$ is 0.45 . Meanwhile, the value of $\beta_{\mathrm{M}}(\mathrm{ds})$ is taken to be 0.4 according to the HAZUS-MH MR5 [6]. This value is used for all types of damage states. The last value of standard deviation is $\beta_{\mathrm{C}}$ which represents the uncertainty of 
structural capacity. The value of $\beta_{\mathrm{C}}$ is 0.4672 . This value is obtained from the variation of structural capacity when the structure is imposed by spectral acceleration in the range of 0.0 to $2.0 \mathrm{~g}$ [25]. All the three standard deviations are finally used to calculate the standard deviation of the total uncertainty ( $\beta \mathrm{ds}$ ) using Equation 15 . The results are summarized in Table 6 and 7.

Table 6. The standard deviations for spectral displacement using inter-story drift ratio HAZUS-MH MR5 (top) and ATC-40 (bottom).

\begin{tabular}{|c|c|c|c|c|c|}
\hline \multicolumn{6}{|c|}{ OPEN FRAME (HAZUS-MH MR5) } \\
\hline \multirow{2}{*}{ Limit State } & $\mathrm{Sd}$ & \multirow{2}{*}{$\beta_{\mathrm{M}(\mathrm{ds})}$} & \multirow{2}{*}{$\beta_{\mathrm{C}}$} & \multirow{2}{*}{$\beta d$} & \multirow{2}{*}{$\beta_{\mathrm{ds}}$} \\
\hline & (m) & & & & \\
\hline Slight & 0.0184 & 0.4000 & 0.4672 & 0.4500 & 0.4519 \\
\hline Moderate & 0.0368 & 0.4000 & 0.4672 & 0.4500 & 0.4519 \\
\hline Extensive & 0.0920 & 0.4000 & 0.4672 & 0.4500 & 0.4519 \\
\hline Complete & 0.2146 & 0.4000 & 0.4672 & 0.4500 & 0.4519 \\
\hline \multicolumn{6}{|c|}{ INFILLED FRAME (HAZUS-MH MR5) } \\
\hline \multirow{2}{*}{ Limit State } & $\mathrm{Sd}$ & \multirow{2}{*}{$\beta \mathrm{M}(\mathrm{ds})$} & \multirow{2}{*}{$\beta_{\mathrm{C}}$} & \multirow{2}{*}{$\beta d$} & \multirow{2}{*}{$\beta_{\mathrm{ds}}$} \\
\hline & (m) & & & & \\
\hline Slight & 0.0187 & 0.4000 & 0.4672 & 0.4500 & 0.4519 \\
\hline Moderate & 0.0374 & 0.4000 & 0.4672 & 0.4500 & 0.4519 \\
\hline Extensive & 0.0935 & 0.4000 & 0.4672 & 0.4500 & 0.4519 \\
\hline Complete & 0.2183 & 0.4000 & 0.4672 & 0.4500 & 0.4519 \\
\hline \multicolumn{6}{|c|}{ OPEN FRAME (ATC 40) } \\
\hline \multirow{2}{*}{ Limit State } & $\mathrm{Sd}$ & \multirow{2}{*}{$\beta \mathrm{M}(\mathrm{ds})$} & \multirow{2}{*}{$\beta_{\mathrm{C}}$} & \multirow{2}{*}{$\beta d$} & \multirow{2}{*}{$\beta \mathrm{ds}$} \\
\hline & $(\mathrm{m})$ & & & & \\
\hline IO & 0.0920 & 0.4000 & 0.4672 & 0.4500 & 0.4519 \\
\hline LS & 0.1840 & 0.4000 & 0.4672 & 0.4500 & 0.4519 \\
\hline SS & 1.1812 & 0.4000 & 0.4672 & 0.4500 & 0.4519 \\
\hline \multicolumn{6}{|c|}{ INFILLED FRAME (ATC 40) } \\
\hline \multirow{2}{*}{ Limit State } & $\mathrm{Sd}$ & \multirow{2}{*}{$\beta \mathrm{M}(\mathrm{ds})$} & \multirow{2}{*}{$\beta_{\mathrm{C}}$} & \multirow{2}{*}{$\beta d$} & \multirow{2}{*}{$\beta_{\mathrm{ds}}$} \\
\hline & $(\mathrm{m})$ & & & & \\
\hline $\mathrm{IO}$ & 0.0935 & 0.4000 & 0.4672 & 0.4500 & 0.4519 \\
\hline LS & 0.1871 & 0.4000 & 0.4672 & 0.4500 & 0.4519 \\
\hline SS & 1.6072 & 0.4000 & 0.4672 & 0.4500 & 0.4519 \\
\hline
\end{tabular}

Table 7. Dispersion structure for spectral displacement using base shear capacity (Silva's Method)

\begin{tabular}{|c|c|c|c|c|c|}
\hline \multicolumn{6}{|c|}{ OPEN FRAME (Silva's Method) } \\
\hline \multirow{2}{*}{ Limit State } & Sd & \multirow{2}{*}{$\beta_{\mathrm{M}(\mathrm{ds})}$} & \multirow{2}{*}{$\beta_{c}$} & \multirow{2}{*}{$\beta d$} & \multirow{2}{*}{$\beta \mathrm{ds}$} \\
\hline & $(\mathrm{m})$ & & & & \\
\hline LS1 & 0.0217 & 0.4000 & 0.4672 & 0.4500 & 0.4519 \\
\hline LS2 & 0.0526 & 0.4000 & 0.4672 & 0.4500 & 0.4519 \\
\hline LS3 & 0.1188 & 0.4000 & 0.4672 & 0.4500 & 0.4519 \\
\hline \multicolumn{6}{|c|}{ INFILLED FRAME (Silva's Method) } \\
\hline \multirow{2}{*}{ Limit State } & Sd & \multirow{2}{*}{$\beta_{\mathrm{M}(\mathrm{d} s)}$} & \multirow{2}{*}{$\beta_{\mathrm{C}}$} & \multirow{2}{*}{$\beta \mathrm{d}$} & \multirow{2}{*}{$\beta_{\mathrm{ds}}$} \\
\hline & $(\mathrm{m})$ & & & & \\
\hline LS1 & 0.0270 & 0.4000 & 0.4672 & 0.4500 & 0.4519 \\
\hline LS2 & 0.1158 & 0.4000 & 0.4672 & 0.4500 & 0.4519 \\
\hline LS3 & 0.2183 & 0.4000 & 0.4672 & 0.4500 & 0.4519 \\
\hline
\end{tabular}


Once the $\beta \mathrm{ds}$ is obtained, the probability of the structure to reach a certain damage state can be estimated using Equation 16. The results are then used to generate the fragility curves of the structure for various damage states (see Figure 5 dan 6).

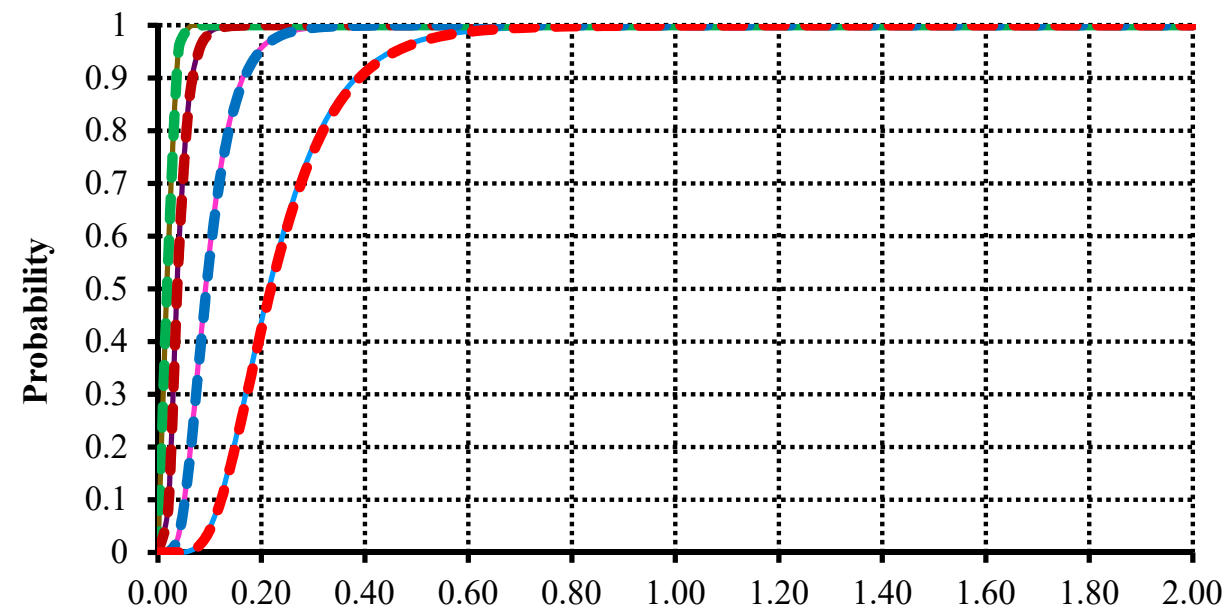

Spectral Displacement (m)
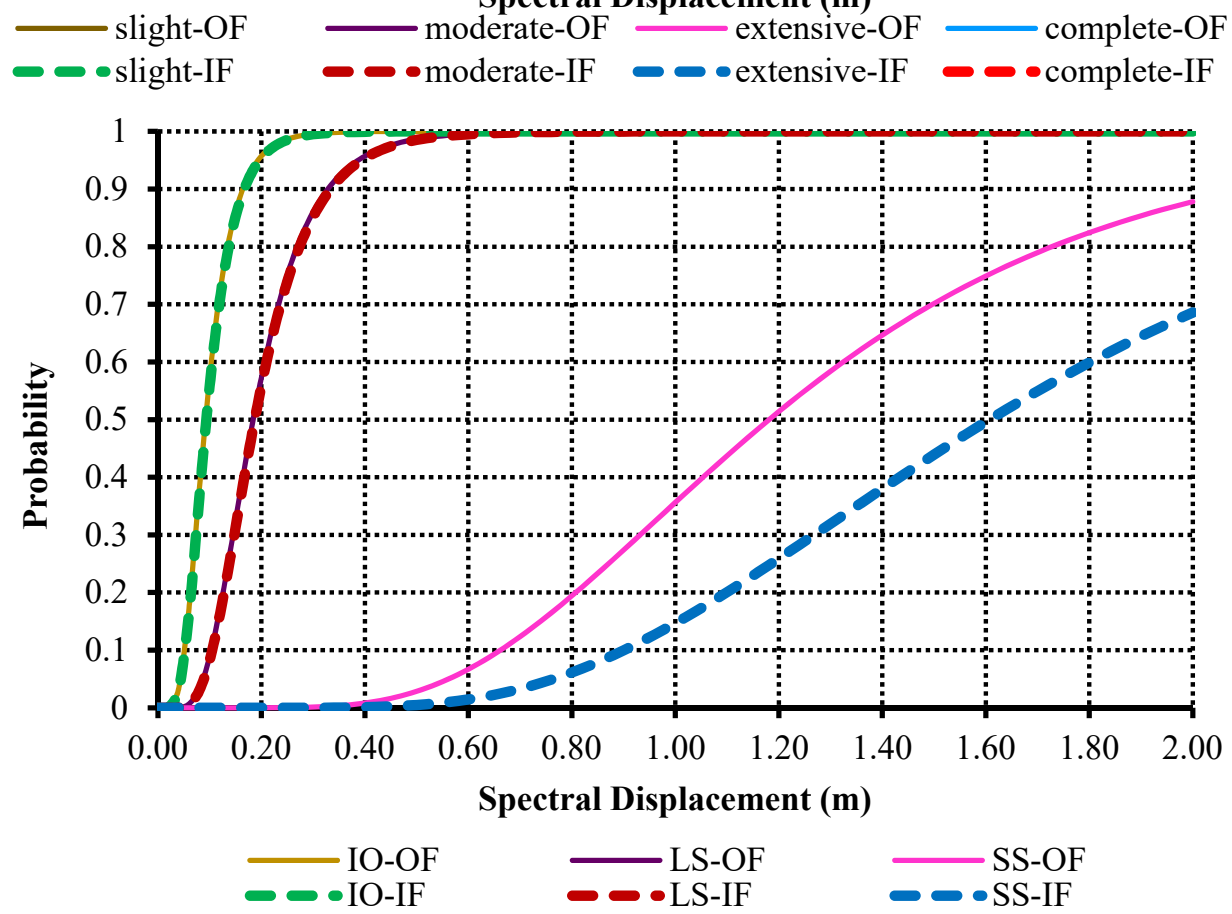

Fig. 5. Fragility curve using inter-story drift ratio HAZUS (top) and ATC40 (bottom).

Figure 5 shows fragility curves determined on the basis of inter-story drift criterion in specifying the damage states. It is obvious from Figure 5 that the fragility curves of the open and infilled frame are similar. This behavior can be expected since the spectrum capacity of the two structures indicates a similarity of the shape. The difference is only observed with respect to the magnitude of spectral acceleration. The infilled frame has a higher spectral acceleration compared to the open frame. However, in term of spectral displacement, the behavior can be regarded to be similar. For this reason, assigning damage state based on the 
inter-story drift criterion tends to give a similar spectral displacement at which the damage state occurs. Consequently, the fragility curve of the open and infilled frame will be alike. The exception is found on the fragility curve for the structural stability (SS) criterion of ATC 40. The method of ATC 40 determines the inter-story drift criterion for the SS is based on the ratio of lateral force to gravity load. Thus, the criterion is basically related to the magnitude of base shear (spectral acceleration). As a result, the fragility curve of the open frame and the infilled frame show a distinctive shape.

Figure 6 shows the differences of the fragility curve of open frame and infilled frame when the criterion of damage states is based on the magnitude of base shear. The difference is pronounced on the fragility curves representing the LS2 and LS3. The difference can be correlated with the influence of masonry infilled wall to increase the base shear capacity (spectral acceleration). Hence, the criterion of damage state based on the magnitude of base shear (the method of Silva et al [9]) is more sensitive to generate fragility curve for the building under study.

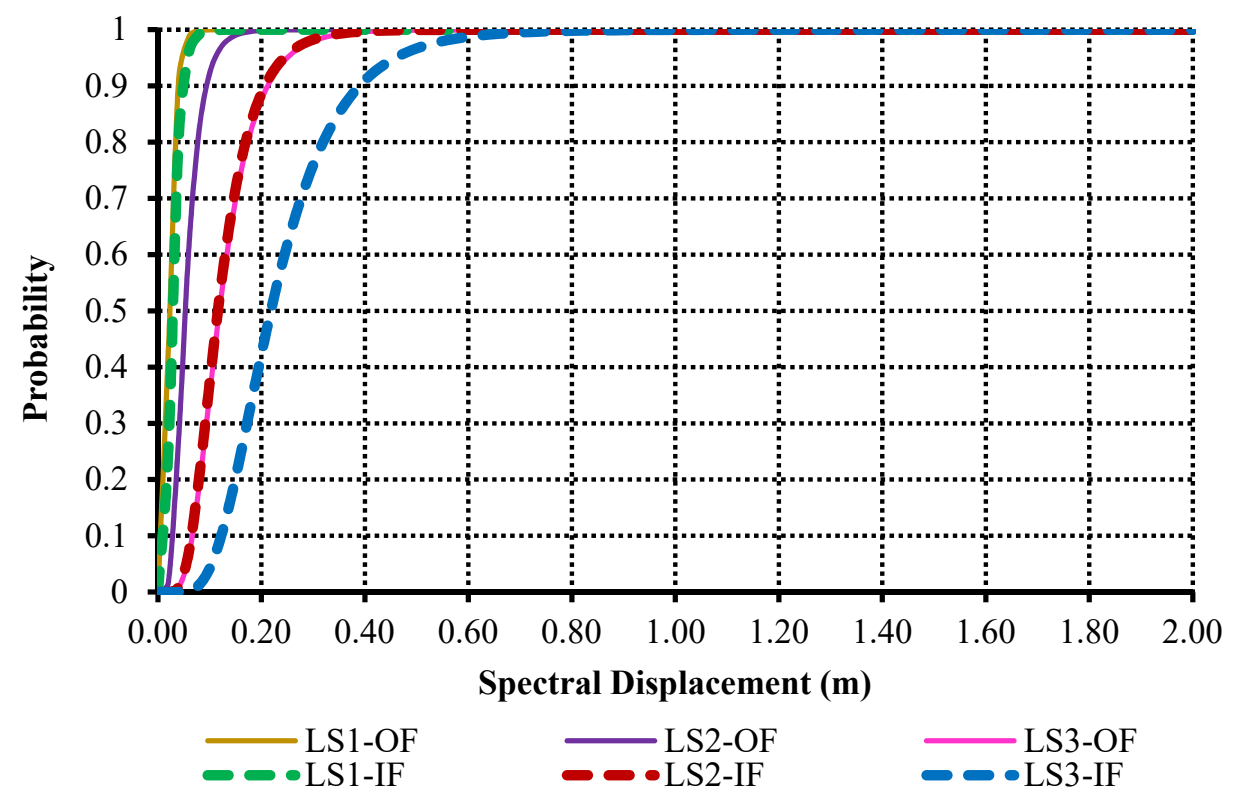

Fig. 6. Fragility curve using base shear maximum.

\section{Conclusions}

The masonry infilled wall influences the seismic performance of the building. The capacity curve of the masonry infilled frame structure is increases compared to the open frame structure. For the building investigated in this study, the increase of the maximum lateral load due to the effect of the masonry infilled wall is about $33 \%$.

Fragility curves have been established for the masonry infilled frame structure and open structure by adopting three criteria of damage states i.e. the HAZUS-MH MR5, ATC 40 and Silva's method. The Silva's method capable to demonstrate the reduction of the probability of the masonry infilled wall structure to reach certain damage states for a given seismic intensity as compared to the open frame structure. On the other hand, the HAZUS-MH MR5 and ATC 40 method cannot demonstrate the influence of masonry infilled wall on the establishment of the fragility curves. The explanation lays on the criteria to determine the damage states. The Silva's method specifies the damage states based on the magnitude of 
base shear (spectral acceleration) while the other methods are based on the inter-story drift. Hence, an increase of base shear capacity due to the masonry infilled wall can only be shown by the fragility curve determined using Silva's method.

\section{References}

1. M. Sukrawa, Penyertaan Dinding Pengisi Dalam Pemodelan Kerangka Beton Bertulang Dan Pengaruhnya Terhadap Hasil Perencanaan Struktur, Prosiding Konferensi Nasional Teknik Sipil, 4, S401-S408 (2010)

2. A. Gautham, K. G. Krishna, Mater. Tod.: Proc., 4, 10565-10569 (2017)

3. F. J. Crisafulli, Seismic Behaviour of Reinforced Concrete Structures with Masonry Infills (Thesis, University of Canterbury, New Zealand, 1997)

4. H. Crowley, R. Pinho, Simplified Equations for Estimating the Period of Vibration of Existing Buildings, First European Conference on Earthquake Engineering and Seismology, 1122 (2006)

5. S. N. A. Saruddin, F. M. Nazri, Proc. Eng., 125, 873-878 (2015)

6. D. Cardone, M. Rossino, G. Gesualdi, Soil. Dyn. Earthq. Eng. (article in press) (2017)

7. FEMA. HAZUS-MH MR5, Advanced Engineering Building Module (AEBM) (Federal Emergency Management Agency, Washington, DC, 2010)

8. ATC-40, Seismic Evaluation and Retrofit of Concrete Buildings (Applied Technology Council Redwood City, CA, volume 1, 1996)

9. V. Silva, H. Varum, H. Crowley, R. Sousa, R. Pinho, Evaluation of Analytical Methodologies to Derive Vulnerability Functions, $15^{\text {th }}$ World Conference Earthquake Engingeering, (2012)

10. J. B. Mander, M. J. N. Priestley and R. Park, ASCE J. Struct. Eng., 114, 1804-1826 (1988)

11. M. Menegotto and P. E. Pinto, Method of Analysis for Cyclically Loaded R.C. Plane Frames Including Changes in Geometry and Non-elastic Behaviour of Elements under Combined Normal Force and Bending, Symposium on the Resistance and Ultimate Deformability of Structures Acted on by Well Defined Repeated Loads, Zurich, Switzerland (1973)

12. F. C. Filippou, E. P. Popov and V. V. Bertero, ASCE J. Struct. Eng., 109, 2666-2684 (1983)

13. F. J. Crisafulli, A. J. Carr, Bull. N.Z. Soc. Earth. Eng., 40, 69-77 (2007)

14. B. E. Wahyudianto, Tinjauan Kuat Tekan dan Kuat Lentur Dinding Pasangan Batu Bata dengan Perkuatan Diagonal Tulangan Baja (Skripsi, Universitas Muhamadiyah Surakarta, 2016)

15. E. Smyrou, Implementation and Verification of a Masonry Panel Model for Nonlinear Dynamic Analysis of Infilled RC Frames (Dissertation, University of Pavia, Italy, 2006)

16. G. J. W. King and P. C. Pandey, Proc. Inst. Civ. Eng., Part 2, 65, 749-760 (1978)

17. F. da Porto, G. Guidi, M. D. Benetta, N. Verlato, combined in-plane/out-of-plane experimental behaviour of reinforced and strengthened infill masonry walls, $12^{\text {th }}$ Canadian Masonry Symposium, (2013)

18. R. E. Klingner and V. V. Bertero, ASCE J. Struct. Div., 104, 973-989 (1978)

19. FEMA 356, Pre-standard and Commentary for the Seismic Rehabilitation of Buildings, (Federal Emergency Management Agency, Washington, DC, 2000) 
20. A. Meslem, D. D'Ayala, Toward Worldwide Guidelines for the Development of Analytical Vulnerability Functions and Fragility Curves at Regional Level, $15^{\text {th }}$ World Conference Earthquake Engineering. (2012)

21. SeismoSoft, Seismostruct-a computer program for static and dynamic nonlinear analysis of framed structures, Available from URL:http//www.seismosoft.com (2006)

22. T. Choudhury, H.B. Kaushik, Eng. Struct., 155, 1-13 (2017)

23. A. Papailia, Seismic fragility curves for reinforced concrete buildings (Dissertation Submitted in Partial Fulfilment of the Requirements for the Master Degree, University of Patras, 2011)

24. Eurocode 8, Design of Structure for Earthquake Resistance-Part 3: Assessment and Retrofitting of Buildings (British Standard, 389 Chiswick High Road, London W4 4AL, 2006)

25. N. Astuti, Rapid and in-depth Analysis for Seismic Risk Evaluation (Thesis, Sebelas Maret University, Surakarta, 2017) 